УДК 78.071(477)

DOI:

Олександра Німилович, доцент кафедри музикознавства та фортепіано Дрогобииького державного педагогічного університету імені Івана Франка

Соломія Добрянська, магістр музичного мистеитва Дрогобииького державного педагогічного університету імені Івана Франка

\title{
УКРАЇНСЬКА ПІАНІСТКА ТАЇСА БОГДАНСЬКА ЗІ США: КОНЦЕРТНО-ВИКОНАВСЬКА ДІЯЛЬНІСТЬ
}

У статті проаналізовано кониертно-сиенічну діяльність української піаністки, педагога, музикознавия і громадської діячки, директорки Українського Музичного Інституту Америки - Таїси Богданської. Музичну освіту Таїса почала здобувати спочатку в Станіславові (тепер Івано-Франківськ) у Тетяни Лепкої, згодом у Вищому музичному інституті ім. М. Лисенка у Львові у відомого піаніста-педагога, учня Василя Барвінського - Романа Савищького. Виїхавщи у 1944 рочі зі Львова, продовжила навчання у Віденській консерваторії у класі проф. А. Королькова-Караліса, Романа Раупенштрауха і Равсан Штравса. Від 1952 року виїхала на постійне проживання до США $і$ знайшла прачю за фахом, як вчителька гри на фортепіано в Українському Музичному Інституті Америки в Нью-Йорку, де праџює й до сьогодні на ниві служіння украӥнському фортепіанному мистеитву і популяризації його в світі. Концертувала у великих містах США: Нюарку, Філядельфії, Ню-Йорку, Маямі, Рочестері, Гранд Кеймен і Вірджін Айлендс, Торонто (Канада), Кюрасао (Японія), Львів, Тернопіль, Івано-Франківськ, Дрогобич (Украӥна), займалась звукозаписуючою справою, публікувала статті про українських виконавців і композиторів.

Ключові слова: Таїса Богданська; фортепіанне виконавство; кониертна практика; платівки; педагогічна діяльність.

תim. 27.

Oleksandra Nimylovych, Associate Professor of the Musicology and Piano Department Drohobych Ivan Franko State Pedagogical University Solomiya Dobryanska, Master of Music Art Drohobych Ivan Franko State Pedagogical University

\section{UKRAINIAN PIANIST TAYISA BOHDANSKA FROM THE USA: CONCERT AND PERFORMING WORK}

The article analyzes the concert and stage work of a Ukrainian pianist, pedagogue, musicologist and public figure, a director of Ukrainian Music Institute of America - Tayisa Bohdanska. She started her music education in Stanislav (now Ivano-Frankivsk) with Tetyana Lepka, later in the Lysenko Higher Institute of Music in Lviv where she tought by the famous pianist-teacher, Vasyl Barvinskiy's student-Roman Savytskiy. After leaving Lviv in 1944, she continued her studies at the Vienna Conservatory in the class of prof. A. Korolkov-Karalis, Roman Raupenshtrauch and Ravsan Strauss. Starting from 1952, she moved to the United States and found a job as a piano teacher at the Ukrainian Music Institute of America in New York, where she continues to work in the field of serving and promoting Ukrainian piano art in the world. She has performed in big US cities, such as: Newark, Philadelphia, New York, Miami, Rochester, Grand Cayman and Virgin Islands, Toronto (Canada), Curacao (Japan), Lviv, Ternopil, IvanoFrankivsk, Drohobych (Ukraine), engaged in recording business, published articles on Ukrainian performers and composers.

The article reveals her pianistic performing skill is characterized by a temperamental, fiery playing, based on her proficiency in chord-octave and finger-shining technique, while achieving a commonality of melody, careful phrase design and a clear articulation of small passages in a fast-paced tempo, the pianist has a unique way of sound extraction, with a soft finger stroke, which causes the middle register of the instrument to sound like a cello with a baritone hue.

T. Bohdanska's work in the conditions of emigration served to develop Ukrainian music and spirituality. In April 2017, a solemn concert took place honoring the artist and on the occasion of the 90th anniversary of her birth, where one could hear words of gratitude to this wonderful person, specialist, pedagogue, musicologist, and "the bright professor" as she is called in music and institute circles. Her artistic figure should serve as an example of creative dedicated work for the present and future generations of talented youth-performing pianists and educators.

Keywords: Tayisa Bohdanska; piano performance; concert practice; records; pedagogical activity.

A ктуальність проблеми. Український і педагог Роман Савицький) - видатна установа Музичний Інститут Америки (1952, української культури в США як у другій половині засновник-знаний український піаніст $\mathrm{XX}$ ст., так і сьогодні. Освітньо-мистецька 
інституція завжди вирізнялася професійністю в доборі педагогічного персоналу, високому рівні навчальних програм, забезпечуючи вихованцям загальну музичну освіту і об'ємний музичний світогляд.

Українська піаністка, педагог, музикознавець і громадська діячка, багаторічна директорка Українського Музичного Інституту Америки Таїса Богданська, отримавши фахову музичну освіту у визначних піаністів-педагогів Романа Савицького (учня Василя Барвінського) у Львові, А. Королькова-Караліса, Романа Раупенштрауха і Равсан Штрауса (у Віденській консерваторії), присвятила себе служінню музичному мистецтву як у концертному, так і педагогічному амплуа. Від 1952 року мисткиня проживає у США, працюючи за фахом, як педагог-піаніст в Українському Музичному Інституті Америки в Нью-Йорку, концертуючи у великих містах США, займаючись звукозаписуючою справою, публікуючи статті про українських виконавців і композиторів. Проте самовіддана праця Таїси Богданської, ії творчість виявились малознаними в Україні.

Мета статті полягає у визначенні, осмисленні, вивченні та аналізі творчого доробку Таїси Богданської у сфері виконавської діяльності й визначенні особливої ролі мисткині у розвитку музичної культури української діаспори.

Аналіз останніх досліджень і публікацій. Дослідженню творчого доробку Т. Богданської присвячена доволі незначна кількість праць. Важливим джерелом постають рецензії та відгуки на її концертно-виконавську палітру. Життєпис творчий шлях мисткині фрагментарно висвітлено у публікаціях Д. Гординської-Каранович, А. Гельбіг i О. Сороки, у статті авторства П. Медведика і Р. Савицького-мол. Р. в Українській Музичній Енциклопедії. Концертну діяльність частково аналізують статті Д. Гординської-Каранович, І. Галій, Л. Яцкевича, О. Кузишин, М. Робак, Л. Хмурович, Р. Савицького-мол. Окремі згадки про виконавську творчість знаходимо у монографії Г. Карась. Велику цінність складають програми концертів як сольних, так і тематичних за участю Т. Богданської, які розкривають ऑii репертуар, широту піаністичної кар'єри. Втім, усі численні наукові матеріали розпорошені й не охоплюють цілісно концертну і фонографічну діяльність T. Богданської.

Виклад основного матеріалу. Піаністка i педагог, музикознавець і громадська діячка Таїса Богданська народилася 11 квітня 1927 у Львові. Родина Т. Богданської походила з Надвірнянського повіту. Дід піаністки священик Микола Голінатий (1858-1914) був посвячений у духовний сане 1883 році. Як душпастир працював від 1883 до 1885 у с. Пнів, Надвірнянського повіту (сотрудник), від 1885 до 1888 у с. Княждвір, Коломийського повіту (сотрудник), від 1888 до 1914 у с. Надорожна, Тлумацького повіту (парох). У шлюбі з Марією Ганкевич (Голіната) народилося четверо дітей, 3 яких син Лев Голінастий (10березня 1897, с. Надорожна - 4 грудня 1984, Монтклер, Нью-Джерзі, США) та його дружина Олександра Дзерович (пом. 1947, Відень) стали батьками піаністки Таїси Богданської [22].

Музичну освіту Таїса почала здобувати спочатку у Станіславові (тепер Івано-Франківськ) у Тетяни Лепкої-Юзвяк - піаністки, музичної викладачки, професора, пластунки, доньки гімназійного професора та визначного культурногромадського діяча Миколи Лепкого, брата Богдана Лепкого, згодом у Вищому музичному інституті ім. М. Лисенка у Львові у відомого піаніста-педагога, учня Василя Барвінського Романа Савицького у Львові (1938 - 44) [7, 671].

У час Другої світової війни, коли чимало українських відомих діячів науки і культури змушені були покидати рідну землю перед радянською окупацією і загрозою, рятуючи свої життя, Таїса, виїхавши у 1944 році зі Львова, продовжила згодом навчання у Віденській консерваторії (яку закінчила з відзнакою, 1951) у класі проф. А. Королькова-Караліса, Романа Раупенштрауха і Равсан Штрауса [18, 69]. У 1952 виїхала на постійне проживання до США. Того ж року, в листопаді, одружилася 3 Петром Богданським і знайшла працю за фахом, як вчителька гри на фортепіано, в Українському Музичному Інституті Америки в Нью-Йорку [14].

Варто кілька слів виголосити про д-ра Петра Богданського (чоловіка піаністки), який народився 6 липня 1912 року в селі Сільці, біля Самбора, закінчив Торгівельну гімназію у Самборі, а після цього був покликаний до польського війська i відбув обов'язкову військову службу. У час німецької окупації України воював на східному фронті й був арештований гестапо у грудні 1941 року. Переживши заслання у концентраційних таборах Авшвіц, Бухенвальд і Дахау, був звільнений з табору в час приходу американських визвольних військ у квітні 1945 року. Як виходець з інтелігентної родини, розуміючи необхідність $і$ потребу в навчанні і отриманні доброї освіти молодий чоловік потрапив до Мюнхена, де в університеті УНРРА студіював суспільноекономічні науки (1945-47) і продовжував студії в Українському Вільному Університеті в Мюнхені (1947-48). Магістерський ступінь П. Богданський здобув у 1948 році, а вже 15 жовтня 1949 року 
захистив докторський ступінь із суспільноекономічних наук. На 39-му році життя, у 1951 році, Петро Богданський приїхав до США, де мріяв розпочати свою кар'єру в економічній царині й докластися до покращення суспільноекономічних умов життя українців у США. Через рік П. Богданський одружився з Таїсою Голінатою. У 1951-54 роках працював у Сетон Гол Університеті в Савт Орандж, Н. Дж., а від 1953 року - у щадниці (кредитівці) “Тризуб” в НьюЙорку $[15,1]$, яка під його головуванням розширила свій фонд від 200 тисяч доларів до 29 мільйонів маєтностей. П. Богданський був членом багатьох наукових і громадських організацій: НТШ, Українського Інституту Америки, головою будівельного комітету Народного Дому в Ірвінгтоні, Н. Дж., членом парафіяльної ради церкви св. Івана Хрестителя в Нюарку й ін. $[1,4]$.

Повертаючись до долі піаністки і педагога Т. Богданської, треба зазначати, що концертну діяльність як піаністка і концертмейстер вона розпочала ще у дитячому віці, навчаючись у Львові у Вищому музичному інституті ім. М. Лисенка в піаніста-педагога, учня Василя Барвінського - Романа Савицького. Опинившись у 1951 році у США продовжувала свою працю у сфері вдосконалення піаністичної майстерності й розпочала свою педагогічну і концертну кар'єру в УМІ, а їі перший концерт в Нью Йорку був наслідком тієї наполегливої праці, яка дала поважні успіхи: “темпераментну, вогнисту гру, засновану на свобідній акордово-октавній і пальцевоблискучій техніці. Один зі своїх перших концертів поза США вона відіграла 26 травня 1961 року, виступивши в Інтернешенел Інстітут оф Метрополитен Торонто в Канаді. Публіка в Торонто зустріла Таїсу Богданську сердечно, 3 захопленням і бурхливими оваціями”, так писала про молоду піаністку учениця В. Барвінського, викладач УМІ Дарія Гординська-Каранович $[4,3]$.

Шевченківські вечори, свято 30-річчя літературної творчості Дарії Ярославської, яке відзначалося 11 січня 1970 року не обходилися без яскравих виступів Таїси Богданської. 26 листопада 1973 року в Нью Йорку в приміщенні Українського Інституту Америки відбувся Ювілейний Концерт 3 нагоди 20-річчя заснування цієї освітньої інституції. У концерті брали участь вчителі: Меланія Байлова, Рафаїл Венке, Володимир Грудин, Дарія Каранович, Антоніна Лисенко, Галина Мирошниченко, Ольга СушковаНаконечна, Надія Оранська, Ігор Соневицький і Таїса Богданська $[25,1]$.

Завдяки Об’ єднанню Українських письменників “Слово” 29 грудня 1974 року в Українському
Інституті Америки в Нью Йорку відбувся вечір в десяту річницю смерті Івана Багряного - поетаписьменника, політичного і громадського діяча. У програмі вечора виступила Т. Богданська, виконавши: прелюдію К. Дебюсі “Затоплена катедра", "Момент розпачу” М. Лисенка і “Експромт” Ф. Шуберта. Як було зазначено в рецензії у часописі “Свобода”: “Музичне виконання пані Богданської надало вечорові святочно-шанобливої атмосфери, за що іiі нагороджено щирими оплесками...” [3, 3].

Важливим моментом у житті піаністки був іiі концерт у славетному залі Карнегі Рісайтл Голл в Нью Йорку 2 грудня 1976 року. "Нюйоркська критика ("Ню Йорк Таймс") прихильно оцінила здорові піяністичні ідеї нашої піяністки, видвигаючи співність мелодії в іiі грі, старанне оформлення фрази і ясну артикуляцію пасажових бігів” $[5,2 ; 27,3]$. У рецензії на цей виступ Д. Гординська-Каранович зазначала, що ріст Т. Богданської-піаністки проявляється не лише в iii піаністичній техніці, а в першу чергу в її здібностях висловлювати їі власне музичне відчуття, головною характеристикою якого є: “життєва радість і тепла, гармонійна емоційність" $[5,2]$. До програми сольного концерту ввійшли Прелюдія і фуга Баха, Соната Бетговена, Експромт Шуберта i Рондо Капрічіозо Мендельсона. До кожного твору піаністка підходила по особливому.

Звичайно не обійшовся iï виступ без українських творів, що сподобалося “нюйоркській критиці”. Три українські твори: Гуцульська соната М. Колеси, Токатина і Куранта В. Косенка. Твори композиторів-земляків були виконані з почуттям і особливим підходом. Як писала Д. ГординськаКаранович: “В гуцульській сонаті М. Колесси, Т. Богданська, здавалось, танцювала і сумовито “завивала" сопілкою, балянсуючи переконливо мелодику з дотепною ритмікою. Токкатіна В. Коссенка була заграна мов подув легкого вітру, а його пісня чуттєво заспівана. Третім твором Косенка була Куранта, старинний, скорий танок, що був виконаний з бравурою” $[5,2]$.

Вітаючи цей виступ піаністки, рецензенти зазначають, що вона досвідчений мистецький педагог, який не обмежується тільки педагогічною, працею, а й виступає з сольними концертами, які розкривають цілий діапазон іiі музичного знання i опанування творчості світових і українських композиторів, яких вона виконує “фахово, тепло, 3 іiї індивідуальним мистецьким полетом” [5, 2].

Уже 21 грудня 1977 року піаністка відгукнулася на запрошення музичної освітньої організації Music Educators Association of New Jersey, inc. i 
виступила в Монтклер, Н. Дж зі сольним концертом, в якому прозвучали твори романтиків.

Проводячи активну виконавську діяльність, Таїса Богданська, як зазначалось у відгуку в часописі “Свобода”, наступний свій концерт відіграла у міській бібліотеці в Елизабет, Ню Джерсі 20 жовтня 1982 року. Павла Горовіц, мистецько-імпрезовий координатор бібліотеки, представила присутнім піаністку, коротко розповівши про ії музичну освіту і здобутки в ролі довершеної піаністки і зазначила, що Таїса Богданська - українка й одним із їі перших вчителів музики був покійний проф. Роман Савицький, син якого, до речі, на той час був працівником цієї бібліотеки. Як зазначила невідома авторка відгуку: "Піяністка своєю безпосередньою невимушеною поведінкою відразу здобула собі симпатію присутніх та нав'язала 3 ними внутрішній зв'язок. Перед кожноразовим виступом, піяністка подавала декілька слів пояснення чи то про даного композитора, чи про саму композицію [24, 2]. У концертній програмі прозвучали твори: Експромт As-dur, оп. 90 Ф. Шуберта; Соната cis-moll (Місячна) Л. Бетховена; Рондо-Капрічіозо $Ф$. Мендельсона; Токатина, Українська пісня та Куранта В. Косенка; Дума В. Довженка; Ноктюрн b-moll, Фантазія-Експромт cis-moll, Тарантела As-dur Ф. Шопена, а на завершення, на біс Етюд Ges-dur (на чорних клавішах) Ф. Шопена.

Публіці до вподоби були розповіді про композиторів, особливо уважними були слухачі, коли Таїса розповідала про українських композиторів, адже, для них вони менш відомі ніж Бетговен, Шуберт чи Шопен. “Не збираюсь давати музичної критики, бо це не моя ділянка, можу тільки сказати що й я разом із іншими слухачами була очарована експресивністю гри Таїси Богданської, а рівночасно хочу підкреслити це, що мене особливо вразило, що вона виступала серед чужинців як пропагатор української музики, так мало їй відомої. Щораз частіше тепер завважуємо в репертуарі наших музик твори українських композиторів й таке ознайомлювання чужинецької публіки 3 нашою музикою, - це велика освідомлююча культуртрегерська праця, яка приносить більше користи чим всяке політикування у своєму гетто" - зазначив В. Шендеровський $[24,4]$. Слід зазначити, що ці концерти були підготовчими перед записуванням першої довгограйної платівки піаністки, яка вийшла у 1983 році.

Незважаючи на таку активну виконавську працю, Т. Богданська робила одночасно й великі успіхи на педагогічній ниві. Жоден концерт, який проводився УМІ Америки у різних його філіях не відбувався без участі її вихованців, з якими завжди на сцені у якості солістки чи акомпаніатора виступала їхній педагог. Свідченням цього може бути концерт відділів УМІ у Філадельфії, який відбувся 6 червня 1982 року. Лев Яцкевич, пишучи про цей захід зазначив, що “концерт той залишив незабутнє враження у добірної публіки, якого виявом були численні оплески, а в багатьох сльози на очах. Всі бо юні виконавці - це наші українські діти, які своєю мистецькою грою на фортепіяні, клярнеті, трубці, скрипці і бандурі зачарували наші серця і полонили наші душі впродовж трьох годин концерту” [26, 3$]$.

Важливою подією в житті піаністки і загалом для розвитку українського виконавства став вихід платівки Таїси Богданської у 1983 році. Оригінальну обкладинку цієї платівки здійснила родичка піаністки Марія Голіната, а фахові нотатки про українських композиторів написав музиколог Роман Савицький-мол.

У своїй статті, присвяченій цій події Дарія Гординська-Каранович чітко описала, які твори ввійшли до платівки і як вони виконані: “Перша сторінка платівки присвячена українським композиторам. Т. Богданська зразу в "Гавоті" М. Лисенка виявила радість музикування, свобідну грайливість танцювальних ритмів і експресивну співучість у середній частині твору. До легко і прозоро відіграної “Токатіни” В. Косенка Т. Богданська застосувала перкусійну техніку, а в "Куранті" того ж композитора показала свою пальцеву скорість із багатобарвними пасажами.

“Дума” Довженка, сповнена національним кольоритом і речетативними прикметами, в руках Т. Богданської набрала переконливої живучості”. “Гуцульська Сонатина” М. Колесси і “Гуцульська Токата" А. Кос-Анатольського були заграні “з віртуозним розмахом” $[6,2 ; 7]$. Д. ГординськаКаранович зазначила, що у Т. Богданської унікальне звуковидобування, її м'який удар звучить наче віолончель 3 іiі баритоновим забарвленням середніх регістрів.

Друга сторона платівки містить знані твори романтичної музичної літератури. Описуючи виконання цих композицій, Д. ГординськаКаранович застосувала чимало образних, схвальних і фахових епітетів: Т. Богданська виконала "Рондо Капрічіозо" Мендельсона "з наснагою і темпераментом з мистецько-логічним переходом від одного до іншого музичного образу"; "Експромт" Шуберта звучить плинно “мов гірська річка, входячи в контрастову емоційну сферу ліричної задуми”, в "Ноктюрні” Шопена “вона була мов співачка, зі своїм 
улюбленим бельканто”, а “Фантазію-Експромт” Шопена піаністка заграла “з нестримною швидкістю, щоб у середній частині переключити себе на протилежні музичні образи з елементами заспокоєння і розмріяности”; “Тарантела” Шопена “заблистіла пікантним ритмом”, а етюд Шопена Т. Богданська “виконала 3 піаністичною вервою (запалом - О. Н., С. Д.)” [6, 7].

Підсумовуючи, авторка рецензії наголосила, що різноманітність програми, представлена на платівці змальовує обшир музичних зацікавлень Т. Богданської й талант до їх реалізації. “Тому не диво, що завдяки своїй всесторонності вона своє музичне знання передає здібним учням і виробляє у них любов до справжньої музичної культури” $[6,7]$. Варто зазначити, що Т. Богданська стала першою піаністкою діаспори, яка записала українську музику на стерео диску [7, 838].

Доволі часто на сторінках україномовного часопису “Свобода” з'являлися анонси концертів українських виконавців чи вечорів, присвячених творчості наших митців. Серед цих, сьогодні цінних оголошень і рецензій-відгуків, які передають атмосферу заходів, майстерність українських митців і становлять цінний фактологічний матеріал для наукових розвідок $\epsilon$ оголошення про проведення 12 лютого 1984 року в Нью-Йорку старанням Українського Музичного Інституту Америки та колишніх учнів в Українському Інституті Америки концерту, присвяченого колишній голові УМІ св. п. проф. Меланії Байловій у п’яту річницю іiі смерті. У програмі брали участь: проф. Таїса Богданська, проф. Лев Стругацький, Марта Аєрбе, Олесь Кузишин, Лариса Магун-Гурин, Марта Мачай та Юрій Фурда [8, 1].

Збагатила своїм виступом Таїса Богданська i мистецьку програму святочної академії в Пасейку. Зусиллями церкви св. Миколая та Відділу УККА 4 листопада 1984 року було відзначено 66-ті роковини Листопадового Зриву та вшановано світлу пам'ять Митрополита Андрея Шептицького. Ввечері, у вщерть заповненій залі Української Централі відбулася святочна академія, яку відкрив коротким словом о. Рафаїл. Церковний хор під керівництвом Зірки Берези виконав два твори: “Отче Наш" Новохатського зі соло Осипа Головацького та “Молитву за вітчизну” з музикою І. Недільського. Після виступу хору на сцену вийшла піаністка T. Богданська, яка відіграла на фортепіано “Прелюдію і фугу” D-dur Баха, “Думу” Довженка та "Гуцульську токату” Кос-Анатольського [2].

Через деякий час Таїса Богданська знову порадувала слухачів тим, що випустила свою другу платівку, присвячену пам'яті покійного чоловіка. Платівка містить три сонати Л. Бетговена. Власне, Т. Богданська є першою українською піаністкою, яка не тільки звернулася до сонат Бетговена, але записала три 3 них на одній платівці, до якої ввійшли: рання Соната Оп. 15 ч. 1, Соната Оп. 27 ч. 2 (“Місячна") і Соната Оп. 31 ч. 3. Як зазначив у рецензії музикознавець Р. Савицький-мол.: "Піяністка простудіювала ці архитвори до найменших подробиць і дала нам свою інтерпретацію згідну із засадами клясицизму і романтизму - двох великих світів, у яких розвивалася Бетговенівська стихія. Вона відповідно відчула стиль “Місячної сонати”, яка находиться на грані тих двох світів... спостерігаємо, що Т. Богданська - чутлива піяністка, яка знає, коли навести сильніший удар, а коли дати музиці нагоду прозвучати більш наспівно. В неї виразний такт, динамічні контрасти і активні відхилення, коли вони потрібні... В цілому це вартісне надбання у нашій громаді, яка не може похвалитись численними платівками клясичної музики" $[17,2]$.

Платівка записана у студії Ар-Сі-Ей (НьюЙорк) на концертному роялі “Стенвей”, який колись належав Сергію Рахманінову. Обкладинку виконали митці: Марія Голіната, Григорій Гивель і Рута Кисілевська $[17,2]$.

У цій же ж статті Р. Савицький-мол. нагадував читачам, що у наступному 1988 році припадає 100 ліття народження композитора-мученика, піаніста, педагога і критика Василя Барвінського, заслуги якого для української культури великі, а його місце в українській музиці високе і почесне. Для гідного відзначення цього ювілею, під патронатом Українського Музичного Інституту Америки задуманий "Проект в століття В. Барвінського", організаторами якого стали тріо музикантів в складі: Марта і Роман Савицькі та німецький піаніст-органіст Михайло Грілл (Мюнхен), великий ентузіаст творчої спадщини В. Барвінського.

У планах цього проекту стало видання диску із записом з автографів невідомих фортепіанних творів В. Барвінського - Сонати та барвистої і репрезентативної “Української сюїти”, віднайдених в архіві Любки Колесси піаністкою Любою Жук. Із цих творів задумано здійснити нову стереоплатівку у виконанні М. Грілла. Р. Савицький-мол. писав, що в планах - низка концертів фортепіанної музики В. Барвінського у великих містах Америки й Канади (починаючи з Нью Йорку) у виконанні М. Грілла; програма у престижному "Радіо Нью-Йорк Таймс" і ювілейні статті в українській пресі та в американських фахових музичних журналах. Такі плани, звичайно, 
вимагали значних фондів, подавалися заклики до української громади у часописах “Свобода” та “Український тижневик” про збирання коштів. I автор статті зазначав: “А в останньому часі начебто прийшов нам на допомогу дух самого Бетговена. Його виконавець Т. Богданська призначила дохід із перших 100 примірників іiі платівки на наш проект. Почин шляхетний. А такими були власне аристократи духа. Бетговен і Барвінський” [17, 2]. Ювілейні, заходи, присвячені 100-річному ювілею В. Барвінського вдалися, все заплановане здійснилося і свою частку у відродження з попелу творчості В. Барвінського внесла і піаністка Т. Богданська.

Продовжуючи свою благочинну працю, вже зі здобуттям Україною незалежності, піаністка активно долучилася до фінансової підтримки українських проектів, даючи чимало концертів, а дохід від них скеровувала на різноманітні культурні цілі. Так, 1 грудня 1991 року у Дітройті в залі школи Непорочного Зачаття 3 концертом побувала відома піаністка Таїса Богданська, яка весь дохід від концерту призначила на відбудову Духовної Семінарії у Львові $[9,1]$. Згодом кошти, зібрані після концертних програм, піаністка передавала для потреб тих, хто став жертвами Чорнобильської катастрофи, для сиротинців в Україні і т.д.

Цього ж року 28-ий Відділ СУА в Нью-Йорку, Н. Дж., влаштував “Вечір в пам'ять письменниці Ольги Кобилянськоі”. У програмі цього вечора брали участь: акторка українських театрів Іванна Кононів і піаністка Марія Павловська акомпаніаторка, а Таїса Богданська виступала у ансамблі з піаністкою Мартою Савицькою. “Піяністка Т. Богданська грала бравурно із питоменним їй темпераментом. Партію оркестри, на другому фортепіяні, грала з мрійним чуттям Марта Савицька. Це був чудово зіграний ансамбль - правдива насолода душі" $[16,6]$. I знову всі зібрані кошти (400 дол.) було призначено на потреби Українського Музею в Нью-Йорку.

Варто зазначити, що Таїса Богданська впродовж свого творчого життя зробила великий внесок у розбудову Ук-раїнського Музею у Нью Йорку. 28-ий Відділ СУА (Союз українок Америки), який очолювала Т. Богданська, станом на 1996 рік зібрав для Українського Музею майже 10.000 доларів. Вагома частка цієї суми пожертви Т. Богданської. Так, у 1990 році вона виступила з концертом в університеті Сітон Голл і прибуток з концерту пожертвувала для Музею. Так само піаністка поступила і з вирученими коштами від концертів у травні 1993 року в Філядельфії, який спонсорувала Філадельфійська
Окружна Управа СУА, передавши їх Музею. Крім того, пожертву надав Музеєві Український Музичний Інститут після концерту в малій залі Карнегі Голл 3 нагоди свого 40-річного ювілею. Певна річ, Т. Богданська брала участь і в цьому концерті. 13 жовтня 1996 року піаністка знову дала концерт в університеті Сітон Голл, і знову прибуток з концерту передала Музеєві.

У концертній програмі цього заходу 13 жовтня в університеті Сітон Голл Таїсою Богданською була виконана програма з творів Баха, Бетговена, Шуберта, Мендельсона, а в другому відділі танці: вальси Брамса, "Мазурка" і “Тарантела" Шопена, “Танок” Барвінського, “Куранта" Косенка, "Гуцульська токата" Кос-Анатольського $[10,2]$. Цей фортепіанний концерт Таїси Богданської став гідним подарунком Українському Музеєві до його 20-річного ювілею.

26 січня 1997 року у приміщенні місцевої середньої школи при Гакровд відбувся концерт Блумфілдського симфонічного оркестру, присвячений 200-літтю Ф. Шуберта. Диригент Едвард Напівоцкі. У програмі - твори Шуберта, Моцарта і Вебера. Власне, Концерт-штюк f-moll on. 79 Вебера для фортепіано з оркестром виконала піаністка Таїса Богданська $[21,4]$.

Важливою подією в діяльності УМІ став вечір на честь Романа Савицького визначного піаніста, педагога і організатора Українського Музичного Інституту Америки, який відбувся у квітні 1998 року. Вступне слово виголосила Дарія ГординськаКаранович, розповідаючи про заслуги митця перед українською музичною культурою, зазначила, що “роля Романа Савицького в історії української музики буде вписана золотими буквами". Надзвичайно живий і хвилюючий виявився спогад патріарха української музики 3 України, зі Львова, композитора і диригента, Миколи Колесси. Звучав він із запису, бо через свій вік (100-річчя попереду!) не міг прибути на цю імпрезу. Несподіванкою був опрацьований образ життя Р. Савицького на хвилях львівського радіо пера музикознавця, професора Львівської консерваторії, Наталії Кашкадамової. Тут був включений і монтаж світлин із життя піаніста, який дбайливо оформив для цього вечора син Романмол. "Учениця Р. Савицького, піаністка Таїса Богданська виконала на фортепіяні в пам'ять про свого улюбленого вчителя Косенкову “Токкатіну”, Довженкову “Думу” та Кос-Анатольського “Гуцульську токкату”. Опісля вона розказувала про свої відносини зі славним нашим піяністом 3 крихтою гумору особистої самокритики" [23, 2]. Двоє учнів Таїси Богданської М. Долл і Л. Долл виконали твори “Їхав стрілець на війноньку” та 
“Їхав козак за Дунай” Р. Савицького. У записах прозвучали твори Барвінського і Ліста у виконанні самого Р. Савицького, які відтворив син Роман слухачам під час програми концерту.

За час своєї концертної діяльності Таїса Богданська встигла побувати і в Україні, зокрема у Львові, Самборі, Дрогобичі (1993), тут вона дала ряд концертів. Закінчивши тур у Відні, вона повернулася 1994 року зі соло-концертом 3 Львівським філармонійним оркестром, виконуючи фортепіанний концерт Вебера під керівництвом Івана Юзюка [7, 428]. У 2000 році вона знову виступала у Львові з сольним концертом, виконуючи твори Мендельсона, Шуберта, Косенка та Кос-Анатольського, а також фортепіанний концерт Cis-dur op. 15 Бетговена 3 Львівським філармонічним оркестром під диригуванням маестро Івана Юзюка.

Доволі часто українська громада Америки проводить День союзянки, який відбувається в Українському культурному центрі. Присутні мали змогу оглянути виставку з діяльності відділів товариства. Було презентовано журнал СУА “Наше життя", фотографії українських експонатів в Музеї еміграції на Еліс-Айленді.

У 2007 році, як і в попередні роки на цьому святі звучала музика і хто, як не Таїса Богданська є прикрасою таких свят. Вона виконала на фортепіано “Токатіну” В. Косенка і “Вальс емоль” Ф. Шопена $[11,9]$. Цього ж року відбувся святковий концерт в честь уродин піаністки і 55ти річчя заснування УМІ, святкували тоді 80-ту річницю від дня іï народження. У святкуванні брали участь учні і вчителі УМІ відділів Нюарку, Норт Арлінгтону, Ню-Йорку і Філадельфії, також колишні учні. Приємною несподіванкою був виступ дипломованого випускника УМІ д-ра Бориса Буняка, який виконав твори, що студіював 3 Т. Богданською багато років назад. Концерт відбувся 29 квітня у Ірвінгтоні. Теплу подяку висловила ювілярка всім тим хто був причетний до організації цього концерту [20, 11 - 12].

В Українському американському культурному центрі Ню-Джерзі у Випані 22 червня 2008 року відбулось храмове свято парафії св. Івана Хрестителя. Службу Божу відправив парох о. Роман Мірчук, після чого відбулася мистецька частина. На сцені виступили танцюристи трьох груп 3 ансамблю “Іскра", яким керує Андрій Цибик, на скрипці виводив чудові мелодії Андрій Гавриш під фортепіанний супровід Таїси Богданської, співали гурти “Троянда" i “Мрія” (це був перший виступ цього жіночого ансамблю) $[12,10]$.

Таїса Богданська сьогодні відома як піаніствиконавець, досвідчений педагог і як один 3 керівників Українського Музичного інституту. Від 1952 року - викладачка УМІА у США (у 197677, 1979-82, від 2000 - його президент) [13, 228]. Опублікувала два томи дитячого фортепіанного репертуару, до яких увійшли твори українських композиторів, які були перевидані у 2000 році в Україні (Тернопіль). Однак цим не обмежується коло їі активної діяльності. Таїса Богданська також самовіддано працює в Союзі Українок Америки (28-ий Відділ) і послідовно підтримує Український Музей у Ню Йорку.

Висновки. Піаністична виконавська майстерність характеризується темпераментною, вогнистою грою, яка базується на вільному володінні акордово-октавною і пальцево-блискучою технікою, досягаючи при тому співності мелодії, старанного оформлення фрази і чіткої артикуляції дрібних пасажів у швидкому темпі, піаністка володіє унікальним звуковидобуванням, з м'яким пальцевим ударом, при якому середній регістр інструменту звучить наче віолончель 3 баритоновим забарвленням. Особлива чутливість піаністки сприяє гармонійному звучанню фортепіано від наповненості і жорсткості звучання до наспівності й ніжності з виразним тактом, динамічними контрастами i активними відхиленнями, коли вони потрібні із унікальним власним музичним відчуттям. 29 квітня 2017 року в залі Українського Народного дому в Ірвінгтоні відбулося святкування 90-річного ювілею мисткині $[19,13]$. До сьогоднішніх днів вона присвячує себе своїм студентам, називаючи їх своїми дітьми, дбаючи про їхній музичний i духовний розвиток, прищеплюючи їм любов до мистецтва, виховуючи їх на кращих зразках світової та української класики. Її мистецька постать повинна слугувати взірцем творчої самовідданої діяльності для сьогоднішніх і майбутніх поколінь талановитої молоді виконавців-піаністів і педагогів.

\section{ЛІТЕРАТУРА}

1. Б. і Т. Богданські - нові меценати Фундації УВУ. Свобода. 1982. Ч. 36. С. 4.

2. В Пассейку відбулася святочна академія. Свобода. 1984. Ч. 232. С. 6.

3. Вечір на пошану Івана Багряного. Свобода. 1974. Ч. 8. C. 3 .

4. Гординська-Каранович Д. Перед концертом Таїси Богданської в Торонто. Свобода. 1961. Ч. 96. С. 3.

5. Гординська-Каранович Д. Таїса Богданська в Карнегі Рісайтл Гол. Свобода. 1977. Ч. 010. С. 2.

6. Гординська-Каранович Д. Платівка Таїси Богданської. Свобода. 1983. Ч. 30. С. 2; 7.

7. Карась Г. Музична культура української діаспори у світовому часопросторі XX століття. Монографія текст. Івано-Франківськ: Тіповіт, 2012. 1164 с. 
8. Концерт присвячений св. п. М. Байловій. Свобода. 1984. Ч. 24. С. 1.

9. Концерт Т. Богданської в Детройті. Свобода. 1991. Ч. 227. С. 1.

10. Концерт Т. Богданської. Свобода. 1996. Ч. 194. С. 2.

11. Кузишин О. День союзянки в Українському культурному центрі. Свобода. 2007. Ч. 49. С. 9.

12. Л. Хмурович. Свято в Українському американському культурному центрі Ню-Джерзі. Свобода. 2008. Ч. 26. С. 10.

13. Медведик П., Савицький-мол. Р. Богданська (Голіната) Таїсія. Українська музична енциклопедія. К., 2006. C. 228.

14. Меценати Фундації Українського Вільного Університету. URL: http://fuvu.org/?page_id=1768 (дата звернення: 21.08.19).

15. Пропам'ятна Книга Українського Музичного Інституту в Америці з нагоди п'ятиліття його існування. Нью-Йорк: Видання Українського Музичного Інституту в Америці, 1958. 65 с.

16. Робак М. Вечір в пам'ять Ольги Кобилянської. Свобода. 1995. Ч. 207. С. 6.

17. Савицький Р.-мол. Бетховен і Барвінський. Свобода. 1987. Ч. 205. С. 2.

18. Савицький Р.-мол. Музика як представник народу (До 50-річчя Українського музичного інституту Америки). Альманах УНС. Парсипані-Нью-Йорк, 2002. Річник 92. С. 169-174.

19. Святкування 90-ліття Таїси Богданської. Свобода. 2017. Ч 16. С. 13.

20. Сорока О. Одночасне відзначення трьох дат. Свобода. 2007. Ч. 20. С. 11-12.

21. Т. Богданська виступить у Блумфілді. Свобода. 1997. Ч. 016. С. 4.

22. Таїса Богданська про українських композиторів. Свобода. 1970. Ч. 207. С. 4.

23. Терен-Юськів Т. Згадуючи засновника УМI i піяніста Р. Савицького. Свобода. 1998. Ч. 072. С. 2.

24. Фортепіяновий концерт Таїси Богданської. Свобода. 1982. Ч. 202. С. 4. C. 1.

25. Ювілейний концерт УМІ. Свобода. 1973. Ч. 217.

26. Яцкевич Л. Враження з концерту відділів УМІ у Філадельфії. Свобода. 1982. Ч. 130. С. 3.

27. Ericson R. Debut of Taissa Bohdanska Cambium Trio Performs Chamber Works Sturdily. The New York Times. 1976. December 05. P. 3.

\section{REFERENCES}

1. B. i T. Bohdanski (1982). - novi metsenaty Fundatsii UVU [Is new patrons of art of Founding of UVU]. Svoboda. part. 36. p. 4. [in Ukrainian].

2. V Passeiku vidbulasia sviatochna akademiia [In Passeyku held Holy Academy]. Svoboda. 1984. part. 232. p. 6. [in Ukrainian].

3. Vechir na poshanu Ivana Bahrianoho [An evening in honor of Ivan Bahrianyj]. Svoboda. 1974. part. 8. p. 3. [in Ukrainian].

4. Hordynska-Karanovych, D. (1961). Pered kontsertom Taisy Bohdanskoi v Toronto [Before the Taisy Bogdanska concert in Toronto]. Svoboda. part. 96. p. 3. [in Ukrainian].
5. Hordynska-Karanovych, D. (1977). Taisa Bohdanska v Karnehi Risaitl Hol [Taisa Bogdanska at Carnegie]. Svoboda. part. 010.p. 2. [in Ukrainian].

6. Hordynska-Karanovych, D. (1983). Plativka Taisy Bohdanskoi [The album of the Sacraments of Bogdanskaya]. Svoboda. part. 30. p. 2; 7. [in Ukrainian].

7. Karas, H. (2012). Muzychna kultura ukrainskoi diaspory u svitovomu chasoprostori XX stolittia [Musical culture of the Ukrainian diaspora in the 20th century World space]. Ivano-Frankivsk, 1164 p. [in Ukrainian].

8. Kontsert prysviachenyi sv. p. M. Bailovii [The concert is devoted to St. P. M. Bajlova]. Svoboda. 1984. part. 24. p. 1. [in Ukrainian].

9. Kontsert T. Bohdanskoi v Detroiti [Concert of T. Bogdanska in Detroit]. Svoboda. 1991. part. 227. p. 1. [in Ukrainian].

10. Kontsert T. Bohdanskoi [The concert of $\mathrm{T}$. Bogdanskaya]. Svoboda. 1996. part. 194. p. 2. [in Ukrainian].

11. Kuzyshyn, O. (2007). Den soiuzianky v Ukrainskomu kulturnomu tsentri [Soyuzyanky Day at the Ukrainian Cultural Center]. Svoboda. part. 49. p. 9. [in Ukrainian].

12. Khmurovych, L. (2008). Sviato v Ukrainskomu amerykanskomu kulturnomu tsentri Niu-Dzherzi [Celebration at the Ukrainian American Cultural Center $\mathrm{Nu}$ Gerzi]. Svoboda. part. 26. p. 10. [in Ukrainian].

13. Medvedyk, P., Savytskyi-mol. (2006). R. Bohdanska (Holinata) Taisiia [Bogdanskaya (Golitnata) Taisia]. Ukrainian Music Encyclopedia. Kyiv, p. 228. [in Ukrainian].

14. Metsenaty Fundatsii Ukrainskoho Vilnoho Universytetu [Patrons of the Ukrainian Free University Foundation]. Available at: http://fuvu.org/ ?page_id=1768[in Ukrainian].

15. Propamiatna Knyha Ukrainskoho Muzychnoho Instytutu V Amerytsi z nahody piatylittia yoho isnuvannia [A memorable book of the Ukrainian Music Institute in America on the occasion of the fifth anniversary of its existence]. New York: Ukrainian Music Institute editions in America, 1958. 65 p. [in Ukrainian].

16. Robak, M. (1995). Vechir v pamiat Olhy Kobylianskoi [Evening in memory of Olga Kobylyanskaya]. Svoboda. part. 207. p. 6. [in Ukrainian].

17. Savytskyi R.-mol. (1987). Betkhoven i Barvinskyi [Beethoven and Barvinskyi]. Svoboda. part. 205. p. 2. [in Ukrainian].

18. Savytskyi R.-mol. (2002). Muzyka yak predstavnyk narodu (Do 50-richchia Ukrainskoho muzychnoho instytutu Ameryky) [Music as a representative of the people (to 50 years of Ukrainian Music Institute of America)]. Almanakh UNS. Parsypani-New York, No. 92. pp. 169-174. [in Ukrainian].

19. Sviatkuvannia 90-littia Taisy Bohdanskoi [Celebration 90-anniversary of Taisy Bogdanskaya]. Svoboda. 2017. part 16.p. 13. [in Ukrainian].

20. Soroka, O. (2007). Odnochasne vidznachennia trokh dat [Simultaneous commemoration of the three dates]. Svoboda. part. 20. pp. 11-12. [in Ukrainian].

21. T. Bohdanska vystupyt u Blumfildi [T. Bogdanskaya 


\section{СУЧАСНІ ПДХОДИ ДО МУЗИЧНО-ВИКОНАВСЬКОЇ СПІВТВОРЧОСТІ СТУДЕНТА І КОНЦЕРТМЕЙСТЕРАЗАКЛАДУ ВИЩОӤ ОСВІТИ}

to perform in Bloomberg]. Svoboda. 1997. part. 016. p. 4. [in Ukrainian].

22. Taisa Bohdanska pro ukrainskykh kompozytoriv [Taisa Bogdanska about Ukrainian composers]. Svoboda. 1970. part. 207. p. 4. [in Ukrainian].

23. Teren-Yuskiv, T. (1998). Zghaduiuchy zasnovnyka UMI i piianista R. Savytskoho [Recalling the founder of the UMI and the pianist R. Savytsky]. Svoboda. part. 072. p. 2. [in Ukrainian].

24. Fortepiianovyi kontsert Taisy Bohdanskoi [Piano
Concert of Taisy Bogdanska]. Svoboda. 1982. part. 202. p. 4. [in Ukrainian].

25. Yuvileinyi kontsert UMI [Jubilee Concert in UMI]. Svoboda. 1973. part. 217. p. 1. [in Ukrainian].

26. Yatskevych L. (1982).Vrazhennia z kontsertu viddiliy UMI u Filadelfii [Impressions from the concert of the UMI in Philadelphia]. Svoboda. part. 130. p. 3. [in Ukrainian]

27. Ericson R. (1976). Debut of Taissa Bohdanska Cambium Trio Performs Chamber Works Sturdily. The New York Times. December 05. p. 3. [in English].

Стаття надійшла до редакції 25.11.2019

УДК 78.071.2:378.091.212:001.83

DOI:

Юлія Харченко, кониертмейстер кафедри теорії $і$ методики музичної освіти та хореографії Мелітопольського державного педагогічного університету імені Богдана Хмельницького

\section{СУЧАСНІ ПІДХОДИ ДО МУЗИЧНО-ВИКОНАВСЬКОЇ СПІВТВОРЧОСТІ СТУДЕНТА І КОНЦЕРТМЕЙСТЕРА ЗАКЛАДУ ВИЩОЇ ОСВІТИ}

У статті проаналізовано окремі теоретичні та практичні питання підвищення якості виконавськоі співпраці концертмейстера і студента. Зазначено, що високий рівень ансамблевої культури дає змогу виконавиям здійснювати пошук ефективних підходів у власній практичній діяльності. Доведено, що чітке усвідомлення відмінності у специифіці сольного і спільного виконавства є одним з провідних приниипів набуття концертмейстером необхідних ансамблевих навичок, умінь та знань. Розглянуті питання історії, теорії, методики, пов'язані з особливостями ансамблевого виконавства. Визначені умови, які забезпечують якість спільного виконавського процесу. Охарактеризовано відповідні професійні і особистісно-значущі якості студента і кониертмейстера, наявність яких забезпечує плідну сумісну роботу.

Ключові слова: спільна музично-виконавська діяльність; співпраия студента і концертмейстера; ансамблева культура; особливості ансамблевого виконавства.

Лim. 12.

Yuliya Harchenko, Concertmaster of the Theory and Methodology of Music Education and Choreography Department, Melitopol Bohdan Khmelnytskiy State Pedagogical University

\section{MODERN APPROACHES TO THE MUSIC AND PERFORMANCE COOPERATION OF THE STUDENT AND CONCERTMASTER IN THE HIGHER EDUCATIONAL INSTITUTION}

The article analyzes some theoretical and practical issues of improving the quality of performance of the concertmaster and student, which is caused by the tasks of vocational training and the requirements that occur in the field of contemporary music pedagogy regarding joint musical and creative activities of the student and the concertmaster. It is noted that the high level of ensemble culture allows the performers to find effective approaches in their practical activity. The necessity of interrelation of ensemble preparation of the concertmaster and the student with the general psychological, pedagogical and methodical preparation that promotes the solution of peculiar creative problems. It is proved that a clear awareness of the differences in the specifics of solo and joint performance, which is one of the leading principles of acquiring the accompanist required ensemble skills and knowledge. The issues of history, theory, techniques related to the features of ensemble performance: musical knowledge culture, personal qualities, problems of interpersonal interaction, creative balance. The conditions that ensure the quality of the joint performance process are defined. The corresponding professional and personallysignificant qualities of the performers, whose presence provides productive work are characterized: artistic thinking, professional orientation, musical abilities, a single auditory perception of a musical work, taking into account the specificity of a musical instrument, quality, communicative qualities. The main stages of working together on a musical work are identified. It is noted that competently work of the concertmaster with the student should become the basis of successful concert and competition performances. It is concluded that the exchange of experience 